\title{
ECOLOGY AND CONSERVATION OF TASMANIPATUS BARRETTI AND T. ANOPHTHALMUS, PARAPATRIC ONYCHOPHORANS (ONYCHOPHORA: PERIPATOPSIDAE) FROM NORTHEASTERN TASMANIA
}

\author{
by R. Mesibov and H. Ruhberg \\ (with two text-figures and four plates)
}

\begin{abstract}
MESIBOV, R. \& RUHBERG, H., 1991 (20:xii): Ecology and conservation of Tasmanipatus barretti and T. anophthalmus, paraparric onychophorans (Onychophora: Peripatopsidae) from northeastern Tasmania. Pap. Proc. R. Soc. Tasm. 125: 11- 16. https://doi.org/10.26749/rstpp.125.11 ISSN 0080- 4703. PO Box 431, Smithton, Tasmania, Australia 7330 (RM); and Zoologischcs lnstitut und Zoologischcs Museum, Universitat Hamburg, Martin-Luther-King-Platz 3, D-2000 Hamburg 13, Germany (HR).

Tasmanipatus barretti and T: anophthalmus are parapatrically distributed in northeastern Tasmania with known ranges of about $600 \mathrm{~km}^{2}$ and $200 \mathrm{~km}^{2}$ respectively. Both species occur in wet sclerophyll forest. Both appear to tolerate habitat disturbance such as occasional bushfires, but are eliminated by forest clearing for agriculture or pine plantations. Both are found in forest reserves, and are to be further protected by a habitat management programme devised by the Tasmanian Forestry Commission.
\end{abstract}

Key Words: Onychophorans, northeastern Tasmania, parapatry, sclerophyil forest, conservation.

\section{INTRODUCTION}

Two rare and unusual species of peripatopsid onychophorans have recently been found in northeastern Tasmania. One species, Tasmanipatus barretti, locally known as the giant velvet worm, is the largest Tasmanian onychophoran. Tasmanipatus barretti extends to $75 \mathrm{~mm}$ in length when walking and is pink-mauve above with a white underside. It was apparently collected and photographed more than 50 years ago (Barrett 1938), although the first museum specimens, from the St Helens area, were taken in 1984. The second species, T. anophthalmus, the blind velvet worm, is eyeless, completely white and up to $50 \mathrm{~mm}$ long. It was first collected near St Marys in 1987 by a party led by N. Tait and D. Briscoe of Macquarie University, New South Wales. Both species are viviparous with 15 pairs of legs.

In this paper details of the distribution, habitats and conservation status of the two rare onychophorans are presented. Taxonomic descriptions are provided in an accompanying article (Ruhberg et al. 1991).

\section{METHODS}

The distribution maps in figures 1 and 2 are based on data from the following unpublished sources: (a) a report on a Tasmanian onychophoran survey by N. Tait and D. Briscoe, 1987 (8 localities); (b) a report on a Tasmanipatus mapping study by RM, 1987 (51 localities); (c) records of incidental collections by RM and P. Bell during a snail survey in the Douglas-Apsley area, 1988 (14 localities); (d) a report on an onychophoran mapping and conservation study in eastern Tasmania by RM, 1988 (34 localities); (e) records of collections by M. Luttrell (T. anophthalmus 1988, 4 localities) and C. Stanley (T. barretti 1988, 1 locality); (f) records of incidental collections by RM during a snail survey near Pioneer, 1989 (11 localities); (g) records of observations during a Tasmanipatus conservation study by R. Taylor and RM, 1989 (4 localities); (h) records of collections by HR and RM during a Tasmanipatusecology study, 1989(13 localities); and (i) records of incidental collections by RM during private field trips, 1984-90 (13 localities).

At each site visited in studies (a), (b), (d) and (h), onychophorans were hunted by gently breaking apart rotting logs and stumps. Less thorough inspections were made under intact logs and fallen limbs, under stones and in wellrotted accumulations of plant litter.

In their natural habitat, such as logs and stumps, onychophorans are easily missed, even by experienced observers. However, it is unlikely that the relatively conspicuous Tasmanipatus species were overlooked at sites where the cryptically-coloured Ooperipatellus insignis (Dendy 1890) was collected (see fig. 1).

Voucher specimens were taken at all but a few localities and were killed and preserved in $70-75 \%$ ethanol or isopropanol. In all cases the locality was recorded as a sixdigit grid reference (e.g. FP028965 for a locality on St Patricks Head), which pinpoints the collecring site within a square $100 \times 100 \mathrm{~m}$. Apart from a small number of specimens required for further study, all voucher material has been deposited in Tasmanian museums (116 T. barretti and $47 \mathrm{~T}$. anophthalmus at the Queen Victoria Museum, Launceston; three $T$. barretti and five $T$. anophthalmus at the Tasmanian Museum and Art Gallery, Hobart).

\section{RESULTS}

\section{Distribution and Habitat}

Tasmanipatus barretti ranges over about $600 \mathrm{~km}^{2}$; the distribution area includes the Avenue/Scamander River, Golden Fleece Rivulet and George River catchments, the Dans Rivulet and Evercreech Rivulet carchments on the upper South Esk River and most of the major coastal creek catchments between St Helens and Chain of Lagoons (fig. 1). Tasmanipatus barretti occurs at about $20 \mathrm{~m}$ elevation within $0.5 \mathrm{~km}$ of the sea at Beaumaris and Four Mile Creek, and above $400 \mathrm{~m}$ elevation near South Sister and Mt Young. In the drier portion of its range, near the coast, it is found along 


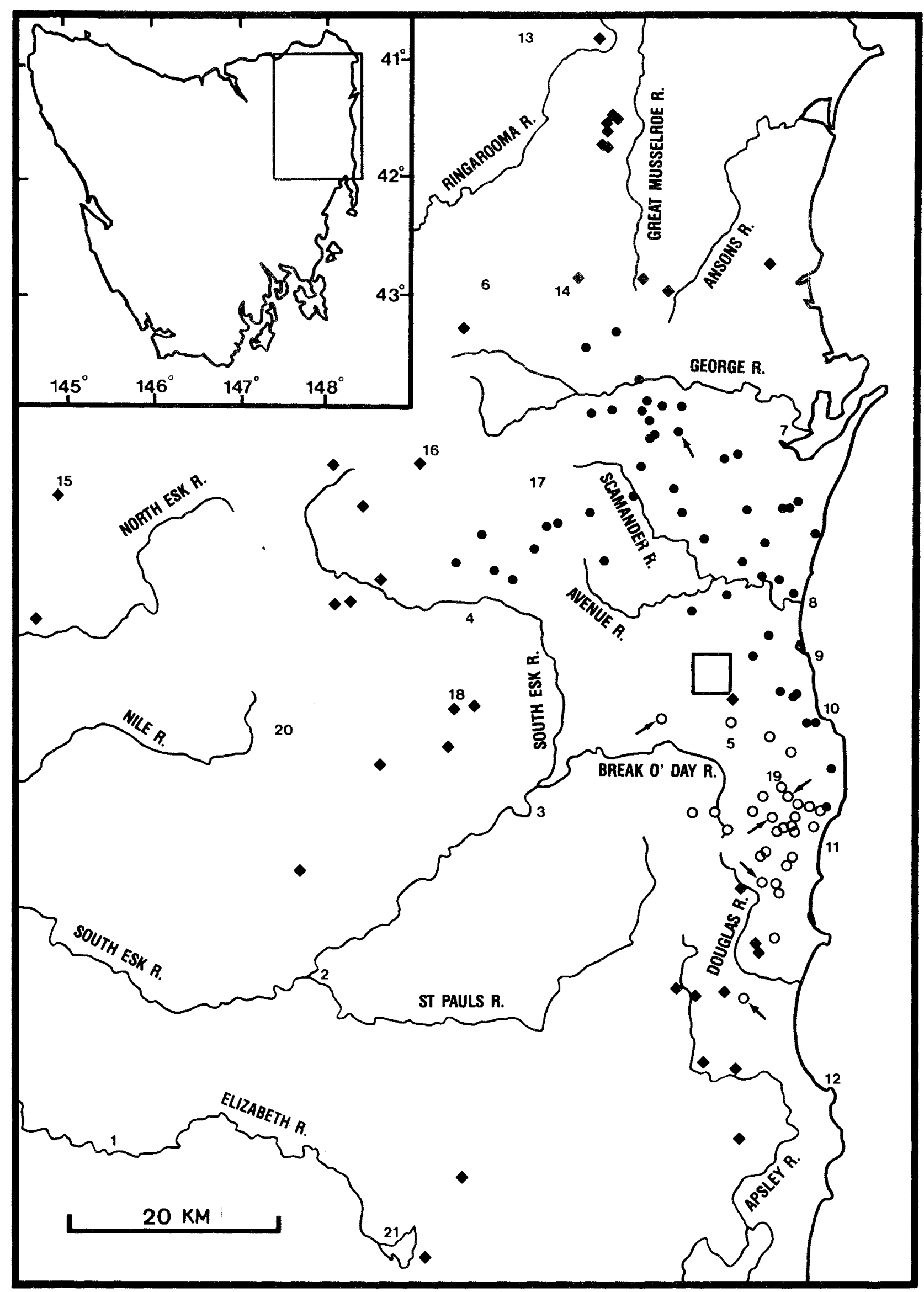




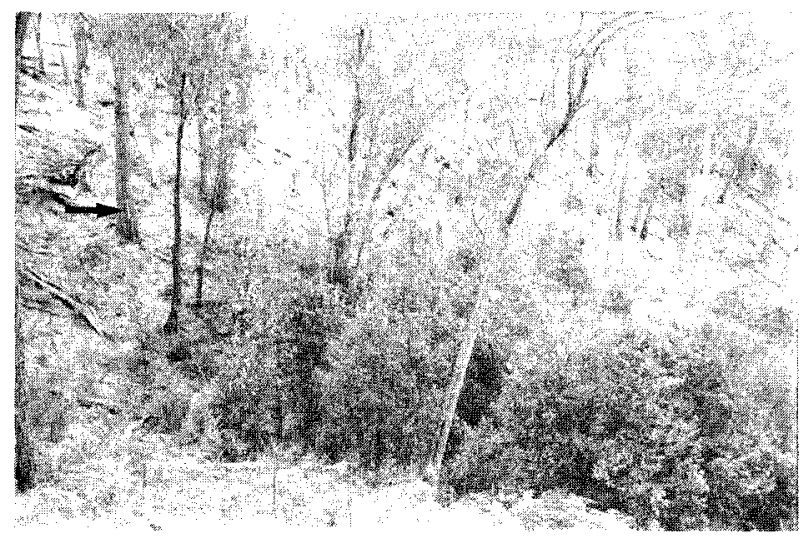

PLATE 1

"Habitat island" along flowline on Skyline Tier, $2 \mathrm{~km}$ west of Scamander. Surrounding forest is almost entirely Eucalyptus sieberi. "Island" vegetation is closed scrub of Pomaderris apetala, Olearia argophylla and Bursaria spinosa. This "island" is populated by T. barretti. White stick leaning against tree (arrow) is $1 \mathrm{~m}$ long.

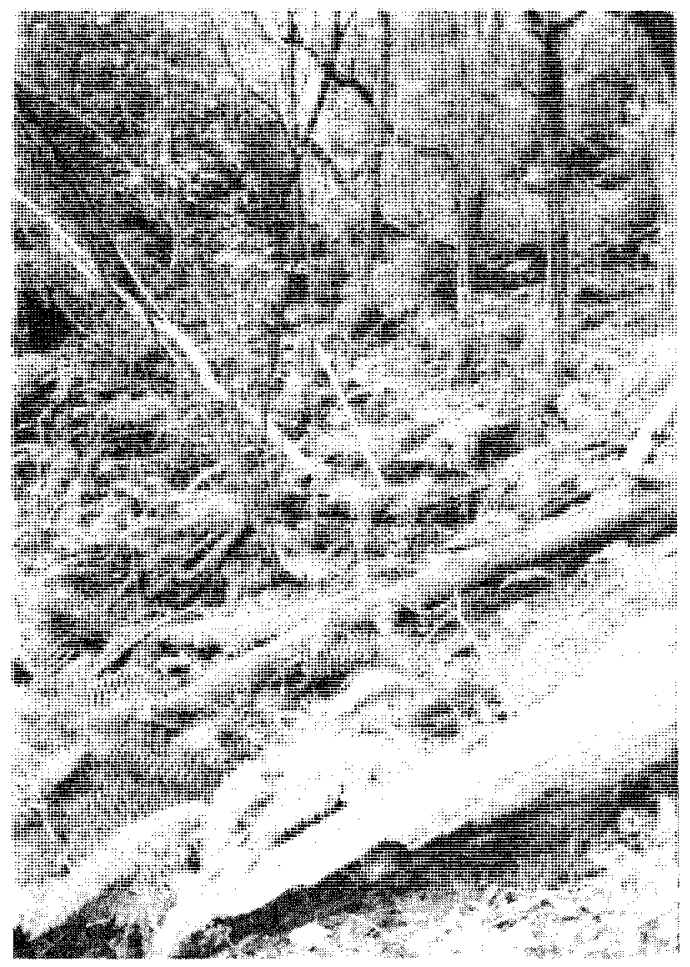

PLATE 2

Inside the "habitat island" of plate 1. Woody litter is mosscovered under 100\% canopy cover. Ground fern is Polystichum proliferum. White stick is $I \mathrm{~m}$ long. flowlines on southeast and east-facing slopes, where ir occurs in gallery forest or scrub, usually with a dense cover of Acacio dealbata, A. melanoxylon, A. verniciflua, Bedfordia salicina, Olearia argophylla, $O$. Lirata or Pomaderris apetala. These gallery formations (pls 1 and 2) are well-defined "habitat islands" of wet sclerophyll vegetation among hills covered in open, dry sclerophyll forest largely dominated by Eucalyptus sieberi. Although $T$. barretti has only occasionally been found in open forest, it typically shelters in E. sieberi logs along flowlines, as well as in logs of the gallery species $E$. globulus and E. viminalis. North and northeast of Mathin na, it may be more or less continuously distributed through blocks of wet sclerophyll forest dominated by $E$. obliqua and $E$. viminalis, with understoreys varying from dense bracken fern to mature Nothofagus cunninghamii and Atherosperma moschatum. Tasmanipatus anophthalmus is apparently restricted to about $200 \mathrm{~km}^{2}$ in the St Marys area (fig. 1). A large proportion of the population lives on the eastern face of Mt Elephant and along the mountain's east- and southrunning flowlines. Other components of the population have been found in the four major coastal drainages immediarely to the south of Mt Elcphant, namely Wardlaws, Piccaninny, Stonyford and Cliff/Doctors Creeks. The remainder of the known distribution consists of scattered records in the Nicholas Range, on St Patricks Head, on the upper Denison Rivulet and upper Douglas River, and on a number of creeks feeding the upper Break O'Day River. Tasmanipatus anophthalmus occurs close to sea level on Little Marsh and Lower Marsh Creeks, and at over $800 \mathrm{~m}$ on South Sister. Throughout its range it is found almost exclusively in wet sclerophyll forest or scrub, whose structure and species composition varies greatly with such factors as elevation, aspect and fire history. On Mt Elephant it lives in a range of habitats from open forests of $E$. delegatensis or E. sieberi to deep gullies shaded by the treefern Dicksonia antarctica; while on lower Piccaninny Creek it occurs in E. globulus gallery forest.

\section{Parapatry}

Tasmanipatus barretti and T. anophthalmusare parapatrically distributed (fig. 1), with a presumed mixing zone about $20 \mathrm{~km}$ long. The mixing zone rises from near sea level north of Chain of Lagoons to about $500 \mathrm{~m}$ at Dublin Town. On Catos Creek (fig. 2), it appears to be less than $50 \mathrm{~m}$ wide, and at one point along this creek a specimen of each species was found in a single eucalypt log. The zone follows no topographic, vegetational or geological discontinuity and for most of its length traverses a deeply dissected, hilly landscape of Devonian granite and pyroclastics (Turner et al. 1984). Three creeks which cross the zone (Catos, Four Mile and Hughes Creeks) are known to have T. anophthalmusliving in the upper part of the catchment and T. barretti in the lower.

FIG. I opposite: - Onychophoran localities in northeastern Tasmania. $\bullet=$ '. barretti, $\mathrm{O}=\mathrm{T}$. anophthalmus, $=$ Ooperipatellus insignis. Closely adjacent localities are indicated by a single symbol. Tasmanipatus localities marked with an arrow are also Ooperipatellus localities. Numbered towns and settlements: (1) Campbell Town, (2) Avoca, (3) Fingal, (4) Mathinna, (5) St Marys, (6) Weldborough, (7) St Helens, (8) Scamander, (9) Falmouth, (10) Four Mile Creek, (11) Chain of Lagoons, (12) Bicheno. Numbered features: (13) Mt Cameron, (14) Blue Tier, (15) Mt Barrow, (16) Mt Victoria, (17) Mt Young; (18) Tower Hill, (19) Mt Elephant, (20) Ben Lomond, (21) Lake Leake. Inset map shows location of main map. For detail within square north of St Marys, see fig. 2. 


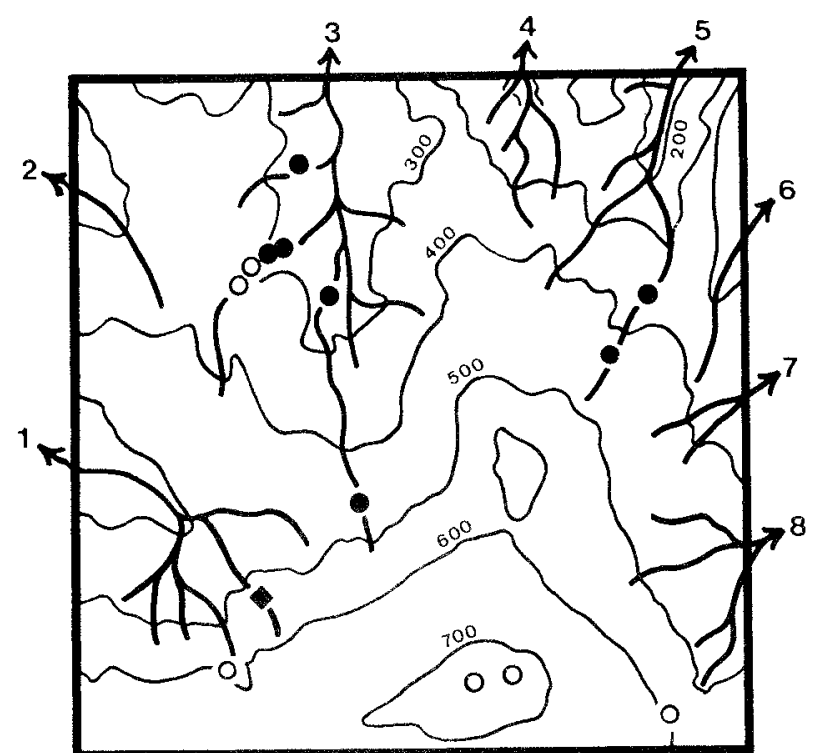

1

FIG. 2-Onychophoran localities in the Dublin Town area, $6 \mathrm{~km}$ northwest of St Marys. $\bullet=\mathrm{T}$. barretti, $\mathrm{O}=\mathrm{T}$. anophthalmus, $\bullet=$ Ooperipatellus insignis. Roads and tracks omitted for clarity. Shaded areas are cleared land. The two hills at lower right are North Sister (above) and South Sister (below). Numbered creeks: (1) and (2) Scales Ck, (3) Catos $C k$, (4) Bolpeys $C k$, (5) Binns $C k$, (6) Workers $C k$, (7) and (8) Yorkys Ck. Map adapted from TASMAP 1:25000 Dublin Toun sheet; contour elevations are in metres.

The oviparous onychophoran Ooperipatellus insignis occurs on both sides of the mixing zone. It was found in the same $\log$ as $T$. barretti at a locality near St Helens, and in the same $\log$ as $T$. anophthalmus at two localities near St Marys.

\section{Microhabitat and Biology}

Both Tasmanipatus species have most often been found in fallen logs of mature eucalypts $(0.5-1 \mathrm{~m}$ in diameter) lying close to flowlines. Both species have been recovered from unburned, surface-charred and deeply burned logs; from bare logs lying in full sun and moss-covered logs under $100 \%$ canopy cover; and from intact, nearly cylindrical logs as well as logs collapsed to ground level. Although within the logs the onychophoran's immediate surroundings were invariably moist, the extent of decay ranged from unrotted wood (specimen under loose bark) to friable material and the claylike "mud guts" associated with termite activity. At two sites T. anophthalmus was found under stones on shaded ground. Tasmanipatus barretti has been collected from the "litter cone" around the base of a standing, mature eucalypt, and from a pile of rotting bark waste about ten years post logging. Neither species has been seen to emerge from shelter at night, although it is believed that both species do so in order to disperse, mate and perhaps hunt. Young $T$. barretti of approximately equal size are sometimes found in close proximity in a single log, suggesting that a brood may shelter together for some time before dispersing.
The microhabitats occupied by the two species are rich in litter fauna, bur neither feeding by, nor predation upon either species has been observed in the field. Associated fauna include triclad flatworms, the land nemertine Argonemertes australiensis, oligochaetes, isopods, amphipods, spiders, mites, the scorpion Cercophonius squama, harvestmen, centipedes, millipedes, symphylans, collembolans, cockroaches, termites, crickets, dipteran larvae, beetle larvae and adults (chiefly carabids, elaterids, lucanids and renebrionids), ants, snails and occasional skinks. In captivity $T$. anophthalmus will eat killed termites and isopods (M. Luttrell, pers. comm.), and T. barretti will catch and eat live workers of Porotermes adamsoni, the common dampwood termite of Tasmania.

One specimen of $T$. anophthalmus gave birth to 12 live and two dead young shortly after her capture (M. Luttrell, pers. comm.); a second female produced 16 live young under similar circumstances. Birth of live young has not yet been observed in T. barretti.

Phoretic mites have been found on both Tasmanipatus species and will be described in a future publication.

\section{Conservation}

Impact

The geographical ranges of T. barretti and T. anophthalmus cannot be drawn precisely on a map, due to the small number of known localities and the evidently fragmented nature of the distributions. Nevertheless, an assessment of European impacts on their combined range has been attempted (Mesibov 1988), and a summary of that assessment is presented here.

From present-day vegetation patterns and a limited number of historical sources (travellers' accounts, local histories and early photographs), it seems likely that, prior to European settlement in the early 1800 s, virtually the whole of the combined range was covered in eucalypt forest and woodland, the largest exception being the Break O'Day Plains, west of St Marys.

To date, only a small proportion of the forest cover has been removed and replaced by pasture, forestry plantations or town developments, three land uses which are incompatible with onychophoran survival. Tasmanipatus barretti has probably lost habitat to farms on Dans and Evercreech Rivulets and the George River, and along the coastal strip berween St Helens and Chain of Lagoons, notably in the wide clearing at Falmouth. Plantations of Pinus radiata have almost certainly displaced $T$. barretti in the Evercreech Rivulet catchment and on Skyline and Loila Tiers, and possibly also at Saddleback Plantation near Mathinna. A significant area on the upper Break O'Day River flats has been developed as pasture; however, it is unclear whether these flats (which included the Break O'Day Plains) supported suitable habitat for T. anophthalmus prior to settlement. In the Mt Elephant area, the $5 \mathrm{~km} \times 5 \mathrm{~km}$ block centred on the Tasman Highway/Mt Elephant Road junction (corners at FP010920, FP060920, FP060870 and FP010870) is known to be well-populated by $T$. anophthalmus, within this block about $12 \mathrm{~km}^{2}$ have been alienated, of which $3.2 \mathrm{~km}^{2}$ have so far been deforested.

Neither Tasmanipatus species seems to suffer from. "edge effects". Juveniles and adults can be found within a few metres of a road clearing or grass paddock. Both species have been collected from selectively logged forest, and at 
abandoned mining sites where the surrounding forest has recolonised disturbed ground.

The impact of fire is of particular interest. There is clear evidence of fire at all but one of the c. 100 sites where either species of Tasmanipatus has been collected. Many of these sites carry eucalypt regrowth dating from an intense establishment fire, or fires, which killed understorey vegetation. A number of collections of $T$. barretti and $T$. anophthalmus were from rot pockets within eucalypt logs with recently burned ends and blackened surfaces (pl. 3); $T$. barretti has been found in charcoal deposits within such logs. From this evidence it is inferred that Tasmanipatus populations will tolerate occasional burning of their forest habitat. However, within the ranges of both species there are forest patches where onychophorans were expected but not found, and where the vegetation pattern and a lack of large logs indicated a history of frequent or very hot burning. Hence, it is concluded that too-frequent burning or fires of too high intensity can eliminate $T$. barretti and $T$. anophthalmus from otherwise suitable forest habitat.

\section{Habitat management}

More than $80 \%$ of the range of $T$. barretti is state forest, most of the remainder being partly cleared private property. The Tasmanian Forestry Commission has recently developed forest-mąnagement guidelines aimed at conserving Tasmanipatus in state forest ( $R$. Taylor, pers. comm.). Fire damage is to be avoided in "habitat islands" of wet sclerophyll vegetation along flowlines and on south- and east-facing slopes, and wildlife priority areas (WPA) have been established in which onychophoran conservation has a higher priority than wood production. In the T. barretti range there are four such WPA, each of which contains relatively large blocks of wet sclerophyll habitat known to be populated by this species, the aggregate area being about 1700 ha. Protection from logging disturbance is also afforded in three forest reserves from which T. barretti has been recorded: Mathinna Falls (250 ha), Evercreech (52 ha), and Scamander (210 ha).

Tasmanipatus anophthalmus is to be conserved in the $\mathrm{Mt}$ Elephant WPA (1950 ha), which overlaps the 300 ha Lower Marsh Creek Forest Reserve. Fire protection for $T$. anophthalmus populations in state forest outside the $\mathrm{Mt}$ Elephant WPA is to be provided under the management guidelines referred to above.

The St Patricks Head State Reserve (150 ha) and the recently proclaimed Douglas-Apsley National Park (about $16000 \mathrm{ha}$ ), both of which contain $T$. anophthalmus populations, are managed by the Tasmanian Department of Parks, Wildlife and Heritage. The Department has not yet announced plans specifically aimed at conserving onychophorans on crown land under its jurisdiction.

No formal protection is available for Tasmanipatus populations on private property.

\section{DISCUSSION}

\section{Absence of Eyes and Pigmentation}

The absence of eyes and pigmentation in T. anophthalmusare characters shared by the South African peripatopsid Peripatopsis alba (Lawrence 1931) and the Jamaican peripatid Speleoperipatus speleus (Peck 1975). However, the latter two species are troglobites restricted in each case to a single cave

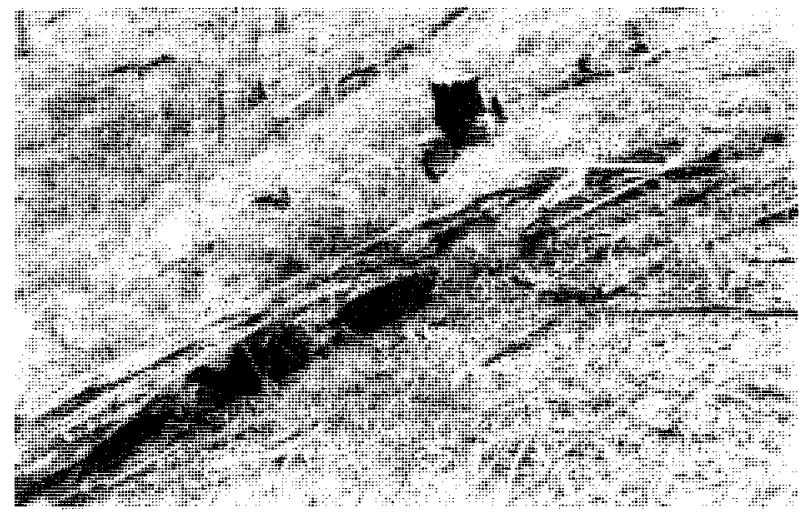

\section{PLATE 3}

A repeatedly burned Eucalyptus sieberi log on Skyline Tier, $2 \mathrm{~km}$ west of Scamader. Tasmanipatus barretti was found sheltering in the wet (downhill) end of this log. White stick is $1 \mathrm{~m}$ long.

system, whereas $T$. anophthalmus occurs in forest litter throughout its known range. In this respect the Tasmanian species resembles the eyeless but pigmented peripatid Typhloperipatus williamsoni, found under stones in scrub jungle in the eastern Himalayan foothills (Kemp 1914).

Speculation that Tasmanipatus anophthalmus may be a cave-evolved species which has adapted to the forest habitat is encouraged by the fact that its distribution overlaps a cluster of Permian limestone outcrops in the St Marys area (Tasmanian Department of Mines 1984), and that the centre of its distribution, Mt Elephant, contains a small cave system (Marthews 1985). However, a 1988 search for T. anophthalmus in several holes and passages in the Mt Elephant karst was unsuccessful (S. Eberhard, pers. comm.).

Two confounding environmental factors need to be considered. The first is that the $T$. anophthalmus range roughly coincides with a high-rainfall anomaly. Moist onshore winds are cooled as they rise up the eastern faces of the hills near St Marys, producing cloud near the summits. Annual rainfall at Gray, on Mt Elephant's southwestern flank, is $1261 \mathrm{~mm}$, compared to $1032 \mathrm{~mm}$ at St Marys and $724 \mathrm{~mm}$ in the nearby coastal town of Scamander (G. Leeds, Bureau of Meteorology, pers. comm.). Another feature of the orogenic rain is the intensity of individual rainfalls, which are believed to be the heaviest in Tasmania (Pilgrim 1987). The second factor is that the T. anophthalmus distribution overlaps that of talus and lag deposits of Jurassic dolerite on the Nicholas Range, St Patricks Head, Mt Elephant and the coastal hills running south from Chain of Lagoons (Tasmania Department of Mines 1984). Examination of this talus at Cheeseberry Hill (pl. 4) and Thompsons Marshes revealed Ooperipatellus insignis and other litter invertebrates in the first metre of depth. It is conceivable that $T$. anophthalmus is living microcavernicolously in the talus, but an assessment of the relative sizes of epigean and hypogean populations of this species would be an extremely difficult undertaking.

In summary, the authors are not convinced that the lack of eyes and pigmentation in $T$. anophthalmus are "cave adaptations", but are unable to explain either the origin or the ecological significance of this combination of features. 


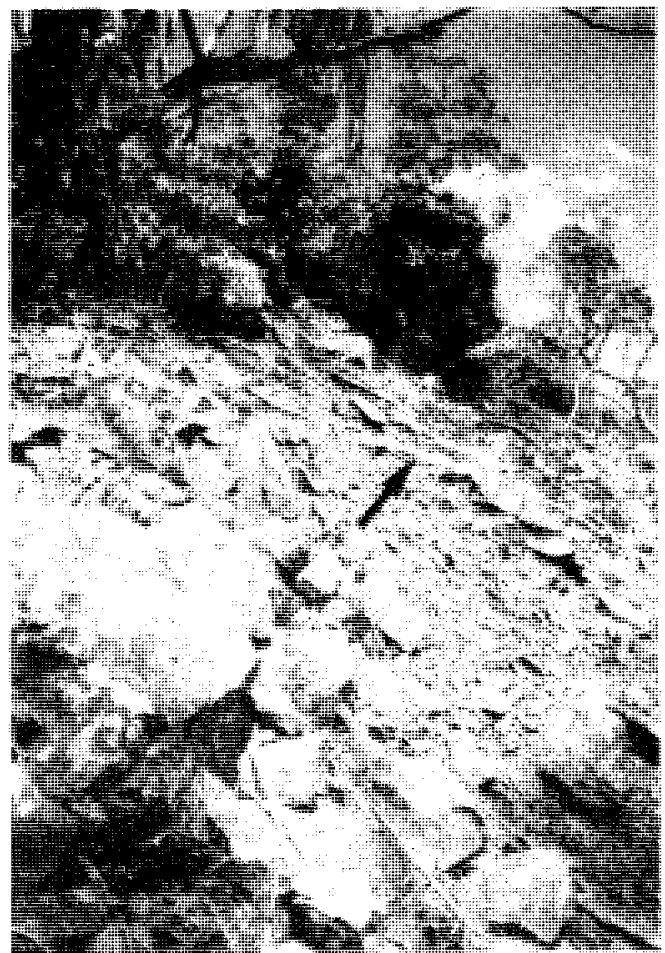

PLATE 4

Dolerite talus on Cheeseberry Hill, $4 \mathrm{~km}$ north of St Marys. White stick (arrow) is $1 \mathrm{~m}$ long.

\section{Parapatry}

The parapatry exhibited by the two Tasmanipatus species is likely to be a Holocene development, since eastern Tasmania is believed to have had a "glacial-arid" climate prior to about 11500 BP (Macphail 1975). The presumed mixing zone may have arisen when the two species moved inland from neighbouring areas of recolonisation close to the present coastline. Because we have recorded only $T$. barretti in the lower reaches of catchments inhabited by both species, and because $T$. anophthalmus is likely to be carried downstream in logs during floods on those creeks, it appears that the former excludes the latter, and that the parapatric boundary may be moving upstream into the range of $T$. anophthalmus.

\section{Management Recommendations}

Habitat management as proposed by the Forestry Commission appears to be a practical means of conserving both Tasmanipatus species over most of their known ranges. The use of cool, fuel-reduction burning in dry forest to protect "habitat islands" of wet sclerophyll forest and scrub is supported. However, the two rare onychophoran species remain at risk of local extinction through catastrophic wildfire, and developments such as the new Four Mile Creek Road (linking Falmouth and Chain of Lagoons) and associated residential clearings are a potential source of fire threatening T. anophthalmus in the Mt Elephant area.

Tasmanipatus barretti and T. anophthalmus could also become locally extinct through overcollecting and destruction of microhabitats by collectors. As a conservation measure, investigators should borrow preserved material from existing collections at the Queen Victoria Museum and Art Gallery, Launceston or the Tasmanian Museum and Art Gallery, Hobart, rather than seek fresh specimens.

\section{ACKNOWLEDGEMENTS}

This study was assisted by grants to RM from the Plomley Foundation and the Australian Heritage Commission, and to HR from the Deutsche Forschungsgemeinschaft (DFG Ru 358/1-5). RM is grateful to Chris Tassell, Queen Victoria Museum and Art Gallery, and to David Rounsevell and Steven Smith of the Department of Parks, Wildlife \& Heritage for their help in obtaining financial support. For permission to cite unpublished information we thank David Briscoe and Noel Tait, Macquarie University; Robert Taylor, Forestry Commission; Stefan Eberhard, University of Tasmania; and Michael Luttrell of Launceston, who carried out a study of T. anophthalmus while a student at St Patricks College. For termite identification we thank Dick Bashford, Forestry Commission. For advice and material assistance in the field we thank Des Howe and Mick Miller, Forestry Commission, Fingal, and Chris Stanley, Cornwall Coal Company, Cornwall. Finally, we are grateful to D.T. Anderson, David Briscoe, Alastair Richardson and Noel Tait for helpful comments on the manuscript.

\section{REFERENCES}

Barreit, C., 1938: A note on Peripatus. Vic. Nat. 55: 11-12. KFap, S., 1914: Onychophora. Rec. Ind. Mus. 8: 471-492.

Mac:Phall, M., 1975: Late Pleistocene environments in Tasmania. Search 6: 295-300.

MATTHEWS, P.G. (Ed.), 1985: AUSTRALIAN KARST INDEX, 1985. Australian Speleological Federation, Inc., Melbourne: 7-8.

Mrsibov, R., 1988: Tasmanian Onychophora. Unpubl. report, Tasmanian Department of Lands, Parks \& Wildlife.

PII.crim, D.H. (Ed.), 1987: AUSTRALIAN RAINFALL AND RUNOFF: A GUIDE TO FLOOD ESTIMATION. Vol. 2, Institution of Engineers, Australia, Sydney; map 1.9.

Rutiberg, H., Mrstbov, R., Briscoe, D.A. \& Tarr, N.N., 1991: Tasmanipatus barrettigen. nov., sp. noy. and T. anophthalmus sp. nov.: two new and unusual onychophorans (Onychophora: Peripatopsidae) from northeastern Tasmania. Pap. Proc. R. Soc. Tasm. 125: 7-10.

Turnhr, N.J., Calver, C.R., Castthiden, R.H. \& Batllie, P.W., 1984: St Marys 1: 50000 series geol. atlas. Tasm. Dep. Mines.

(accepted 7 December 1990) 